\title{
PERANCANGAN SISTEM KOPERASI KARYAWAN MENGGUNAKAN QRCODE UNTUK MENINGKATKAN PELAYANAN PADA KOPERASI PT. INTIKEMAS PUTRA MAKMUR
}

\author{
Nur Azizah ${ }^{1}$, Oleh Soleh ${ }^{2}$, Ning Yuli Astuti ${ }^{* 3}$ \\ ${ }^{1,2,3}$ Program Studi Sistem Informasi Fakultas Sains dan Teknologi Universitas Raharja \\ E-mail : ${ }^{1}$ nur.azizah@ raharja.info, ${ }^{2}$ oleh.soleh@ raharja.info, ${ }^{* 3}$ ning@ raharja.info
}

\begin{abstract}
Abstrak
Koperasi karyawan PT Intikemas Putra Makmur merupakan suatu unit layanan karyawan yang tersedia di PT Intikemas Putra Makmur. Koperasi PT Intikemas Putra Makmur diadakan untuk melayani kebutuhann dari karyawan PT Intikemas Putra Makmur itu sendiri. Pendataan pada koperasi karyawan PT Intikemas Putra Makmur saat ini masih menggunakan buku koperasi dan menginputnya ke dalam Microsoft Excel yang diatur secara manual oleh pengurus koperasi. Sistem yang berjalan saaat ini belum berjalan dengan baik dikarenakan masih terdapat beberapa kekurangan, diantara lainnya anggota koperasi membutuhkan waktu lebih lama untuk mengajukan permohonan pinjaman, karena harus menemui petugas koperasi untuk meminta formulir permohonan pinjaman. Petugas koperasi harus mencatat setiap transaksi anggota ke dalam buku koperasi, kemudian merekap kembali ke dalam Microsoft Excel . Pengadaan buku koperasi membutuhkan dana dan juga rentan hilang, karena hanya di simpan di kardus tempat petugas koperasi, kemudian untuk karyawan yang sudah resign, buku anggota koperasinya menjadi sampah dokumen. Rekapan laporan transaksi kurang aman, karena disimpan di dalam Microsoft Excel yang rentan akan kesalahan penginputan ataupun manipulasi data karena tidak ada menu login untuk mengakses laporan. Pelayanan koperasi karyawan berbasis web, menggunakan metode analisa PIECES. Perancangan sistem menggunakan Notepad++ untuk Text editor, Framework Yii, bahasa pemrogaman menggunakan bahasa PHP, dan metode transaksi menggunakan scan QR Code. Sistem ini dapat memudahkan petugas dalam pelayanan, dan mengurangi terjadinya human error. Sistem yang diusulkan dapat membuat format laporan transaksi dengan lebih rinci dan rapi. Keamanan data terjamin karena terdapat hak akses dari masing-masing devisi, mengefisiensikan waktu petugas koperasi dalam pelayanan transaksi dan pembuatan laporan.
\end{abstract}

Kata Kunci-Anggota, Koperasi

\begin{abstract}
Intikemas Cooperative Employees of PT Putra Makmur is a unit of employee services available in PT Intikemas Putra Makmur. Cooperative Intikemas Putra Makmur held to serve the needs of employees of PT Putra Makmur Intikemas itself. Logging on cooperative employees of PT Putra Makmur Intikemas currently still using cooperative book and then input book into Microsoft Excel are set manually by the cooperative board. The system runs does not yet go well because there are still some shortcomings, among other cooperative members need more time to apply for a loan, because it must meet the cooperative officers to ask for a loan application form. Officers must record each transaction cooperative member into the cooperative book, then recap back into Microsoft Excel. Procurement of books cooperatives need funds and are also vulnerable missing, because it is stored in cardboard place cooperative officers, then to employees who have resigned, the book cooperative members into the garbage documents. Recaps transaction reports less secure, since it is stored in Microsoft Excel that are vulnerable
\end{abstract}


to error or manipulation of inputting the data because there is no login menu to access the report. Web-based employee cooperative services, using PIECES analist method. Notepad++'s system design using Text editor, Yii Framework, using the programming language PHP language, and transaction method using scan the QR Code. This system is expected to facilitate the officer in the performance, and reduce human error. The proposed system can make a format with more detailed transaction reports and tidy. Data security is assured because there are the permissions of each masing division, streamline time cooperative officers in service transactions and preparing reports.

Keyword-Members, Cooperative

\section{PENDAHULUAN}

Teknologi informasi turut berkembang sejalan dengan peradaban zaman. Perkembangan teknologi informasi tidak hanya mempengaruhi dunia bisnis tetapi termasuk juga kegiatan koperasi. Koperasi adalah sebuah organisasi ekonomi yang dimiliki dan dioperasikan oleh orang-orang demi kepentingan bersama. Koperasi melandaskan kegiatan berdasarkan prinsip gerakan ekonomi rakyat yang berdasarkan asas kekeluargaan. Pada prinsipnya semua jenis koperasi sama, namun pada koperasi karyawan, anggotanya hanya terbatas pada karyawan sebuah perusahaan tersebut. Dengan kekuatan jumlah karyawan untuk menggalang dana dan menjalankan roda usaha, koperasi karyawan mempunyai peluang dan peranan yang sangat penting untuk kemajuan perusahaan itu sendiri. Sebuah perusahaan yang memiliki puluhan, ratusan atau ribuan karyawan adalah aset manusia dan kapital yang luar biasa jika dimanfaatkan dan dikelola dengan benar. Koperasi Karyawan merupakan bentuk koperasi yang paling stabil karena keanggotaan yang tetap. Metode penarikan simpanan mudah karena bisa melalui sistem potong gaji. Dengan kelebihan tersebut koperasi karyawan seharusnya memiliki peluang besar untuk berkembang.

PT. Intikemas Putra Makmur adalah perusahan flexible packaging yang baru merintis pengadaan koperasi karyawan. Koperasi yang dijalankan pada PT. Intikemas Putra Makmur masih berupa koperasi simpan pinjam, namun pada kedepannya akan diadakan jual beli bahanbahan pokok / sembako untuk keperluan karyawan. Pada saat ini koperasi pada PT. Intikemas Putra Makmur memiliki anggota sejumlah 300 anggota, transaksi yang dijalankan pada koperasi masih berupa simpanan wajib senilai Rp. 25.000,- setiap bulannya, dan tercatat sebanyak 25 anggota yang telah melakukan peminjaman, serta terdapat 20 anggota yang melakukan simpanan sukarela setiap bulannya, dan anggota lainnya hanya melakukan transaksi simpanan wajib. Sedangkan untuk sistem yang dijalankan pada Koperasi Karyawan PT. Intikemas Putra Makmur masih tergolong manual, yaitu menggunakan Microsoft Excel sebagai penginputan data karyawan serta data simpanan dan pinjaman, berikut juga penghitungan jumlah bunga simpan/ pinjamnya. Kemudian pengurus koperasi akan mencetak data simpanan / pinjaman anggota perbulannya dan menempel pada mading perusahaan. Dalam perkembangannya, koperasi PT Intikemas Putra Makmur membutuhkan sistem yang lebih modern untuk memudahkan admin koperasi dalam penginputan data dan transaksi. Juga membutuhkan media penyalur yang lebih mudah diakses oleh masing - masing anggota, sehingga pengurus koperasi tidak perlu mencetak data simpan/pinjam setiap bulannya, dan data transaksi anggota cukup diketahui oleh anggota yang bersangkutan itu sendiri dan pengurus koperasi.

Koperasi adalah perkumpulan otonom dari orang - orang yang bersatu secara sukarela untuk memenuhi kebutuhan - kebutuhan dan aspirasi ekonomi, social dan budaya bersama sama melalui perusahaan koperasi yang dimiliki bersama dan dikendalikan secara demokratis.[1] Koperasi adalah badan usaha yang beranggotakan orang seorang atau badan hukum koperasi dengan melandaskan kegiatannya berdasarkan prinsip koperasi sekaligus sebagai gerakan ekonomi rakyat yang berdasar atas asas kekeluargaan (Pasal 1 UU no. 25 Tahun 1992 tentang perkoperasian). Karyawan adalah setiap orang yang bekerja dengan menjual 
tenaganya (fisik dan pikiran) kepada suatu perusahaan dan memperoleh balas jasa yang sesuai dengan perjanjian. Karyawan merupakan kekayaan dalam suatu perusahaan. Aktivitas perusahaan tidak dapat berjalan apabila tanpa adanya keikutsertaan karyawan.

Sistem pembayaran adalah sistem yang mencakup seperangkat aturan, lembaga, dan mekanisme yang digunakan untuk melaksanakan pemindahan dana guna memenuhi suatu kewajiban yang timbul dari suatu kegiatan ekonomi (UU tentang Bank Indonesia pasal 1, angka 6). Sistem pembayaran juga terdiri dari serangkaian sub-sistem atau sub komponen (alat pembayaran, kelembagaan, infrastuktur) yang secara bersama-sama membentuk suatu kesatuan yang diperlukan dalam perpindahan nilai uang (transfer of value) dari satu pihak ke pihak lainya perpindahan dana dalam berbagai pengertian sistem tersebut bisa dilakukan dalam bentuk yang sederhana yang hanya melibatkan dua pihak/individu secara langsung. Kebutuhan akan suatu sistem komputerisasi pada zaman sekarang ini mencakup kesegala bidang yang berhubungan dengan penerapan teknologi informasi. Setiap perusahaan swasta maupun pemerintahan sangat membutuhkan sistem komputerisasi yang relevan, akurat, cepat, dan efisien. [2] Ketersediaan informasi yang cepat dan akurat serta didukung dengan penerapan sistem yang optimal menjadi kelebihan sendiri harus dimiliki setiap perusahaan. Quick Response Code sering di sebut $Q R$ Code atau kode QR adalah semacam simbol dua dimensi yang dikembangkan oleh Denso Wave yang merupakan anak perusahaan dari Toyota sebuah perusahaan Jepang pada tahun 1994. Tujuan dari $Q R$ Code ini adalah untuk menyampaikan informasi secara cepat dan juga mendapat tanggapan atau respon secara cepat.[3]

Perancangan Sistem adalah suatu kegiatan membuat desain teknis berdasarkan kegiatan pada waktu proses analisis. Perancangan disini dimaksudkan suatu proses pemahaman dan peran suatu sistem informasi berbasis komputer. [4] Pelayanan merupakan kegiatan yang dilakukan oleh seseorang atau sekelompok orang dengan landasan tertentu dimana tingkat pemuasannya hanya dapat dirasakan oleh orang yang melayani atau orang yang dilayani, tergantung kepada kemampuan penyedia jasa dalam memenuhi harapan pengguna.[5]

\section{METODE PENELITIAN}

Metode penelitian merupakan suatu tata cara atau kegiatan pelaksanaan penelitian rangka untuk mengumpulkan informasi atau data serta melakukan investigasi terhadap data yang telah didapatkan tersebut. yang didasari oleh asumsi-asumsi dasar, pandangan-pandangan filosofis dan ideologis, pertanyaan dan isu-isu yang dihadapi. Suatu penelitian mempunyai rancangan penelitian tertentu. Rancangan ini menggambarkan prosedur atau langkah-langkah yang harus ditempuh, waktu penelitian, sumber data dan kondisi arti untuk apa data dikumpulkan dan dengan cara bagaimana data tersebut dihimpun dan diolah untuk dianalisa dalam pembuatan laporan.

\section{a. Metode Observasi (Observasi Research)}

Pada tahapan ini penulis melakukan pengamatan langsung dari objek penelitian untuk mendapatkan data dan informasi yang akurat dan lengkap dari berbagai pihak yang terkait dan berhubungan dengan tema penelitian yang berhasil penulis rumuskan di bagian finance.

\section{b. Metode Wawancara (Interview Research)}

Penulis melakukan wawancara Manager Keuangan dan Purchasing yang mengolah data keuangan, penulis mendapatkan informasi berkaitan dengan penelitian penulis.

\section{c. Metode Studi Pustaka (Studi Literature)}

Selain melakukan Observasi penulis juga melakukan data dengan cara studi pustaka dalam metode ini penulis berusaha untuk melengkapi data-data yang diperoleh dengan membaca dan mempelajari dari buku-buku dan data-data yang relevan dalam pemilihan judul yang penulis ajukan. Buku dan data tersebut digunakan penulis untuk membantu penganalisaan dan perancangan yang dilakukan. 


\section{Metode Analisis Data}

Pada penelitian ini, metode analisa dilakukan dengan langkah-langkah melakukan pengamatan dan analisa terhadap sistem yang berjalan saat ini, serta menentukan UML (Unified Modeling Language) yang meliputi use case diagram, activity diagram, sequence diagram.

\section{Metode Analisa PIECES}

Analisa PIECES adalah analisa yang melihat sistem dari Performance, Information/Data, Economic, Control/Security, Efficiency, dan Service.

\section{HASIL DAN PEMBAHASAN}

Untuk dapat menggambarkan prosedur secara keseluruhan diperlukan beberapa tahapan analisa sebagai bentuk pengumpulan informasi guna mendapatkan model yang sesuai dengan kebutuhan dan mampu memberikan solusi dengan cepat secara efektif dan efisien, mulai dari tahapan pengumpulan informasi dan kebutuhan, analisa dokumen, merancangan hubungan antar dokumen sampai dengan merancanga model diagram database dan model rancangan sistem. Beberapa tahapan yang dimaksud sampai dengan model rancangan yang diciptakan dapat dilihat pada gambar $1,2,3,4,4$.

\section{Use Case Diagram Prosedur Berjalan}

Berdasarkan gambar use case Diagram (gambar 1) yang berjalan saat ini sistem yang mencakup seluruh kegiatan pada sistem pengajuan peminjaman. Terdapat 4 (empat) Actor yang melakukan kegiatan yaitu anggota yang mengisi form pengajuan peminjaman, sekretaris yang berfungsi untuk cek data anggota dan membuat laporan peminjaman, bendahara berfungsi untuk cek saldo koperasi, cek data pinjaman, memberikan uang pinjaman, dan membuat bukti peminjaman uang, kemudian ketua harian yang berfungsi untuk memberikan persetujuan peminjaman.

Terdapat juga 8 (delapan) use case yang merupakan proses yang terjadi pada sistem berjalan yaitu mengisi form pengajuan peminjaman yang melibatkan anggota, mengecek data anggota yang melibatkan sekretaris, mengecek saldo koperasi dan data pinjaman yang melibatkan bendahara, memberikan persetujuan peminjaman yang melibatkan ketua harian, memberikan uang pinjaman dan membuat bukti peminjaman uang yang melibatkan bendahra, dan pembuatan laporan peminjaman yang melibatkan sekretaris.

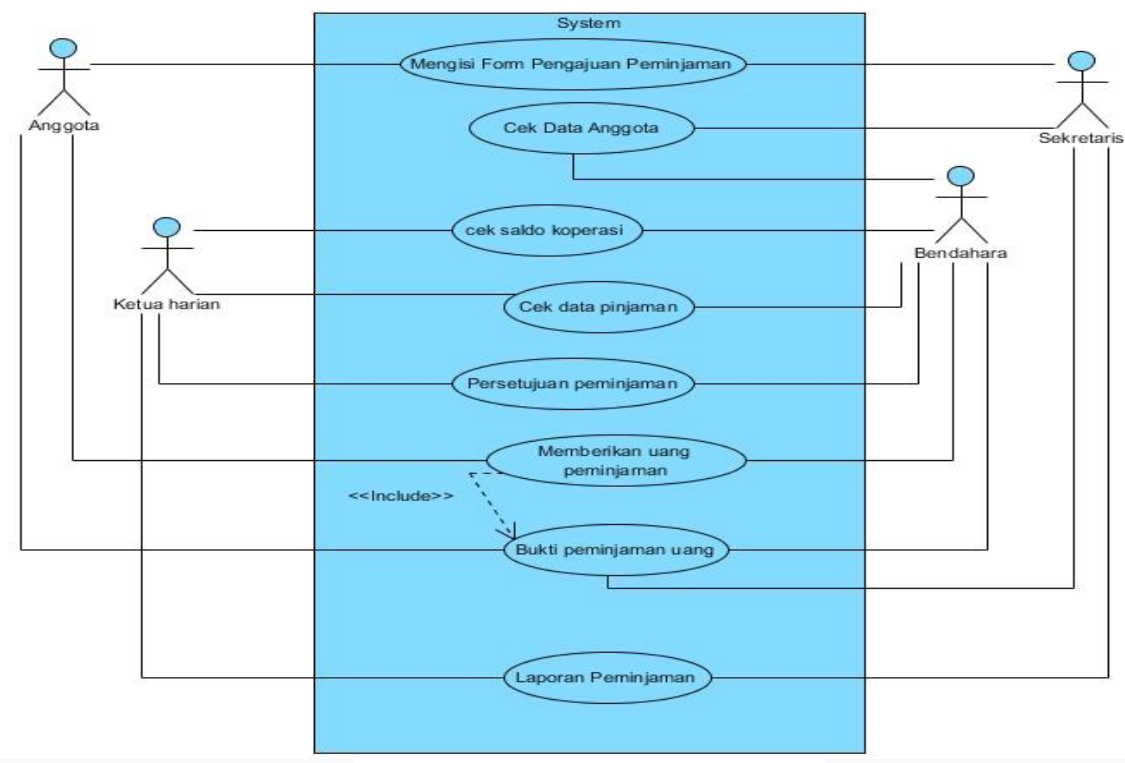

Gambar 1. Use case Diagram 
ISSN: 2461-1409

Online ISSN: 2655-5298

\section{Activity Diagram Prosedur Berjalan}

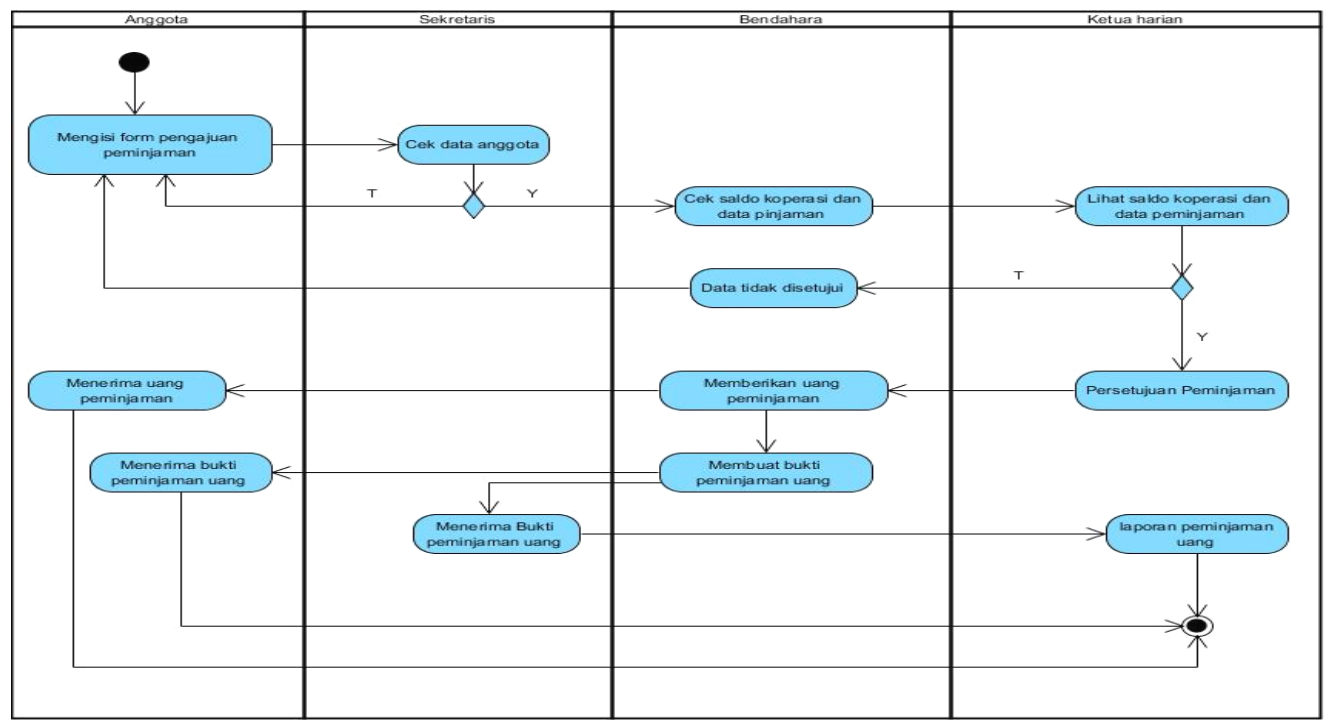

Gambar 2. Activity Diagram

Berdasarkan gambar activity diagram (gambar 2) yang berjalan saat ini sistem mencakup seluruh kegiatan pengajuan peminjaman. Sistem ini melibatkan 4 (empat) Actor yaitu, anggota mengisi form pengajuan peminjaman, kemudian sekretaris mengecek data anggota, jika data tidak sesuai maka pengajuan ditolak, jika data anggota sesuai maka bendahara akan mengecek saldo koperasi dan data peminjaman, kemudian menyerahkan kepada ketua harian, ketua harian akan melihat saldo koperasi dan data peminjaman, jika data tidak sesuai maka peminjaman akan ditolak, jika disetujui maka bendahara akan memberikan uang pinjaman kepada anggota, dan membuat bukti peminjaman uang, setelah itu sekretaris akan membuat laporan peminjaman dan menyerahkan kepada ketua harian.

\section{Sequence Diagram Prosedur Berjalan}

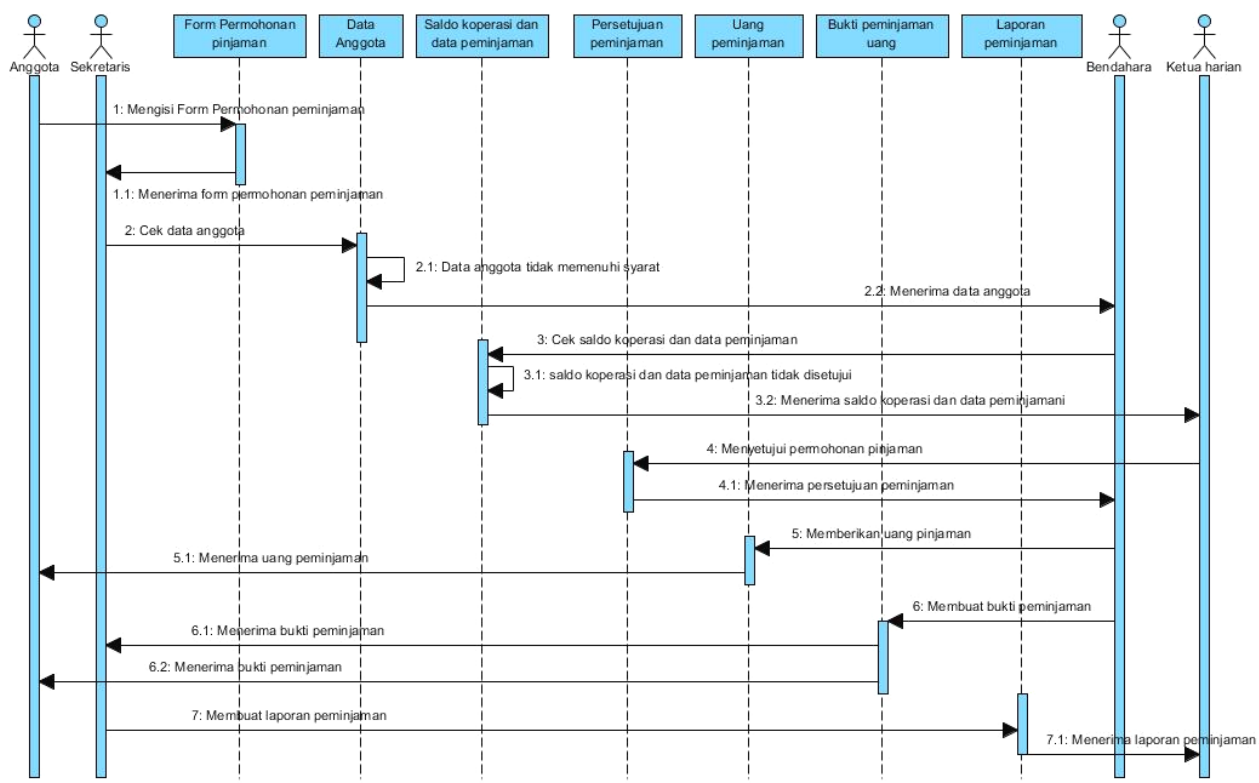

Gambar 3. Sequence Diagram 
Berdasarkan gambar sequence diagram (gambar 3) yang berjalan saat ini terlihat 4 (empat) actor yang melakukan kegiatan diantaranya: anggota, sekretaris, bendahara, ketua harian, yang akan menyelesaikan 17 message spesifikasi dari komunikasi antar objek yang memuat informasi-informasi tentang aktifitas yang terjadi, yaitu Anggota mengisi form permohonan peminjaman, sekretaris menerima form permohonan peminjaman, sekretaris cek data anggota, jika data tidak memenuhi syarat, maka form tidak disetujui, bendahara menerima data anggota dari sekretaris, jika data anggota memenuhi syarat, bendahara cek saldo koperasi dan data peminjaman, jika saldo koperasi dan data peminjaman tidak disetujui, maka form akan kembali, ketua harian menerima saldo koperasi dan data peminjaman dari bendahara, ketua harian menyetujui permohonan peminjaman, bendahara menerima persetujuan peminjaman, bendahara memberikan uang pinjaman kepada anggota, anggota menerima uang peminjaman, bendahara membuat bukti peminjaman, sekretaris menerima bukti peminjaman, anggota menerima bukti peminjaman, sekretaris membuat laporan peminjaman, ketua koperasi menerima laporan peminjaman.

\section{Class Diagram Usulan}

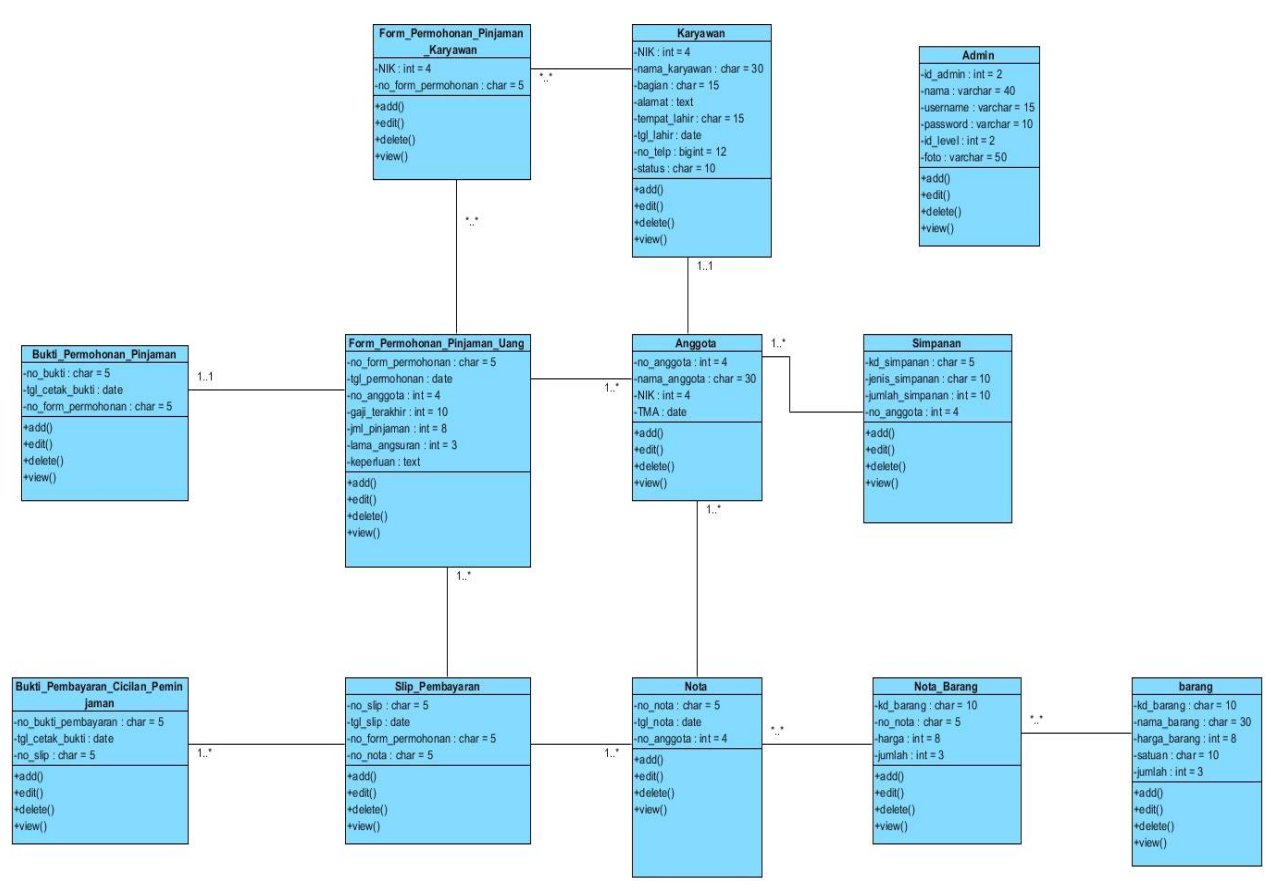

Gambar 4. Class Diagram Usulan

Berdasarkan gambar class diagram Usulan (gambar 4) terdapat 12 (dua belas) class, himpunan dari objek-objek yang berbagi atribut serta operasi dan 12 (dua belas) Association, hubungan antara objek satu dengan objek yang lainnya. 


\section{Use Case Diagram Usulan}

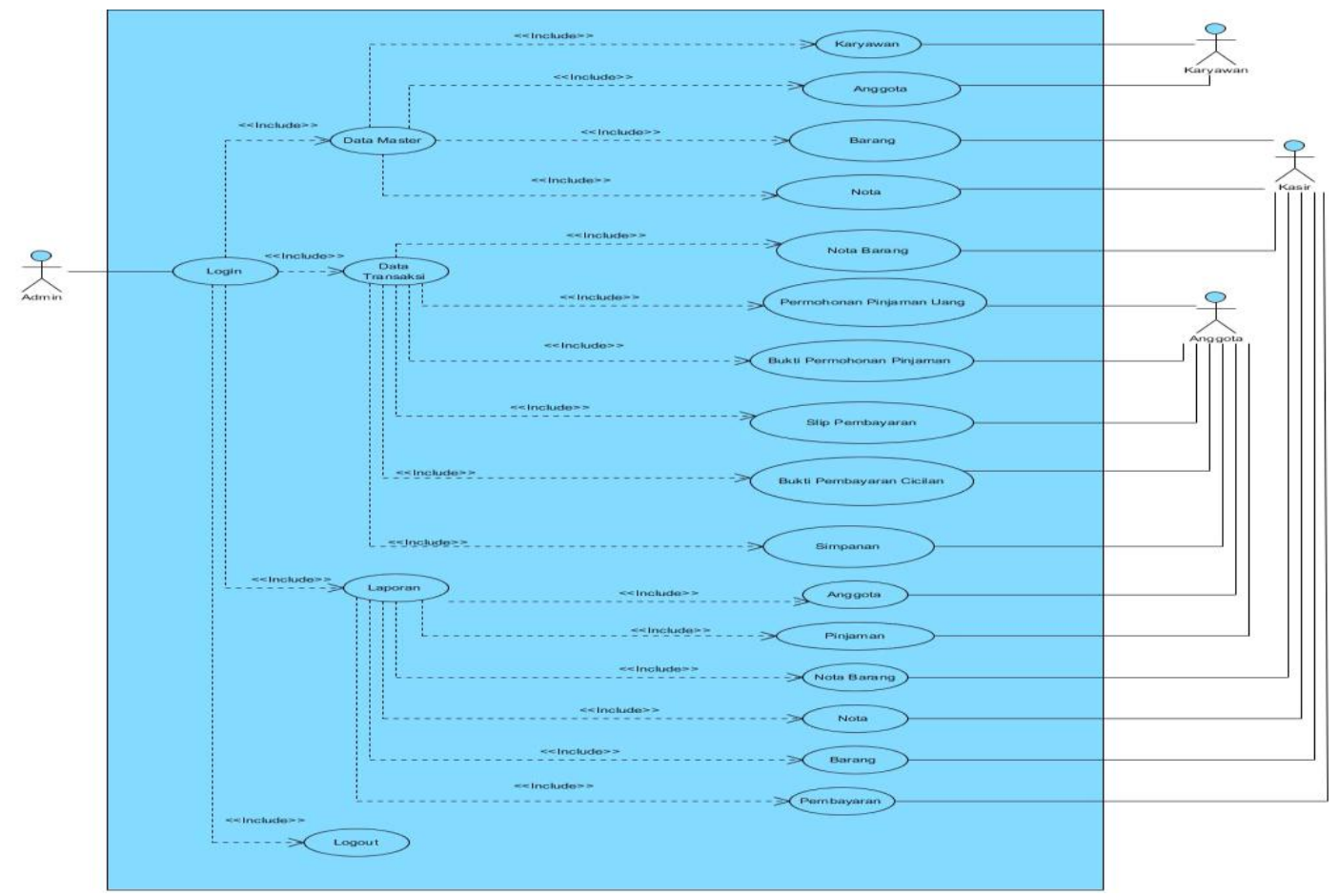

Gambar 5. Use Case Diagram Admin Usulan

Berdasarkan gambar use case diagram admin usulan (gambar 5) 1 ( satu ) sistem yang mencakup seluruh kegiatan yang dilakukan oleh admin Koperasi PT Intikemas Putra Makmur. Terdapat 4 ( lima ) actor yang terlibat di dalam sistem, yaitu admin, karyawan, kasir, dan anggota. Terdapat 21 use case yang dapat dilakukan oleh admin, yaitu login, pilih data master, input karyawan, input anggota, input barang, input nota, pilih data transaksi, input nota barang, input permohonanpinjaman uang, input bukti permohonan pinjaman, input slip pembayaran, input simpanan, pilih laporan, lihat laporan anggota, lihat laporan pinjaman, lihat laporan nota barang, lihat laporan nota, lihat laporan barang, lihat laporan pembayaran, pilih logout.

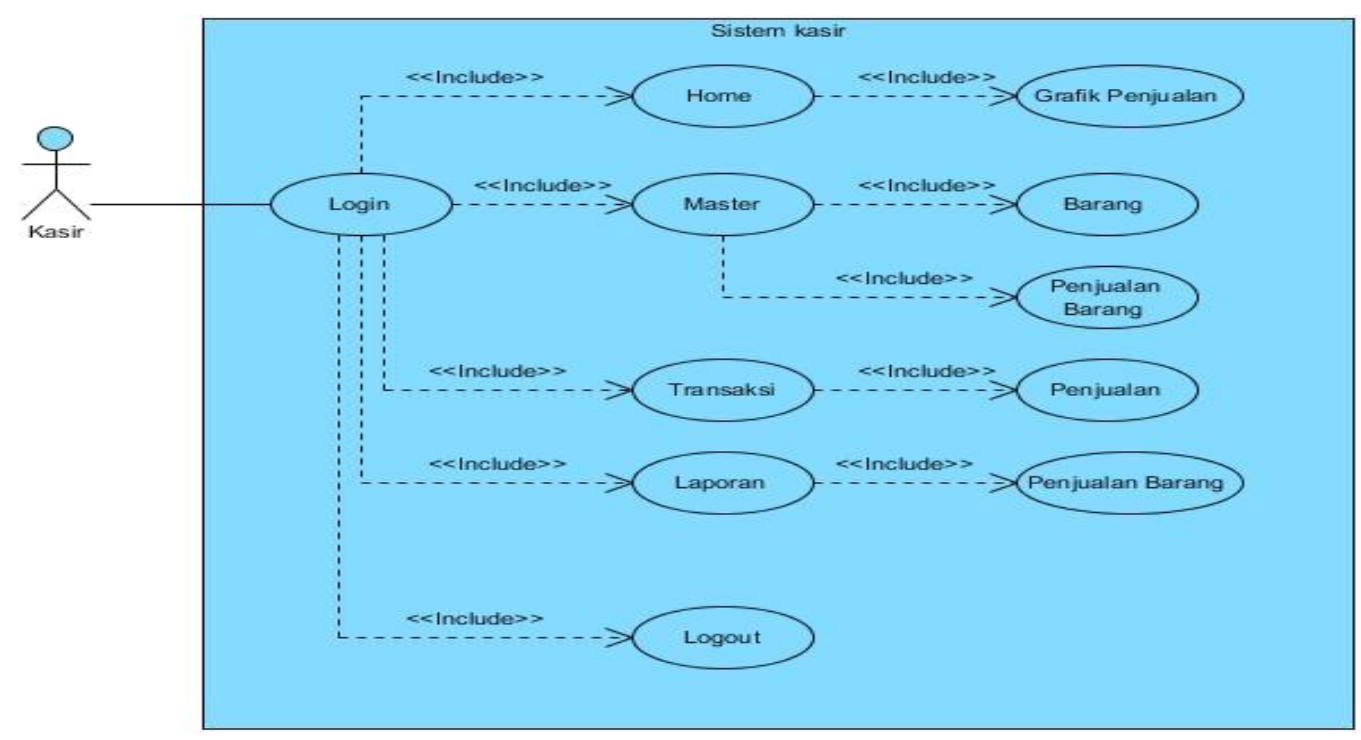

Gambar 6. Use Case Diagram Kasir Usulan 
Berdasarkan gambar use case diagram kasir usulan (gambar 6) 1 ( satu ) sistem yang mencakup seluruh kegiatan yang dilakukan oleh kasir Koperasi PT Intikemas Putra Makmur. Terdapat 11 use case yang dapat dilakukan oleh kasir, yaitu login, pilih home, lihat grafik penjualan, pilih master, input barang, transaksi penjualan barang, pilih transaksi, melakukan penjualan, pilih laporan, lihat laporan penjualan barang, pilih logout.

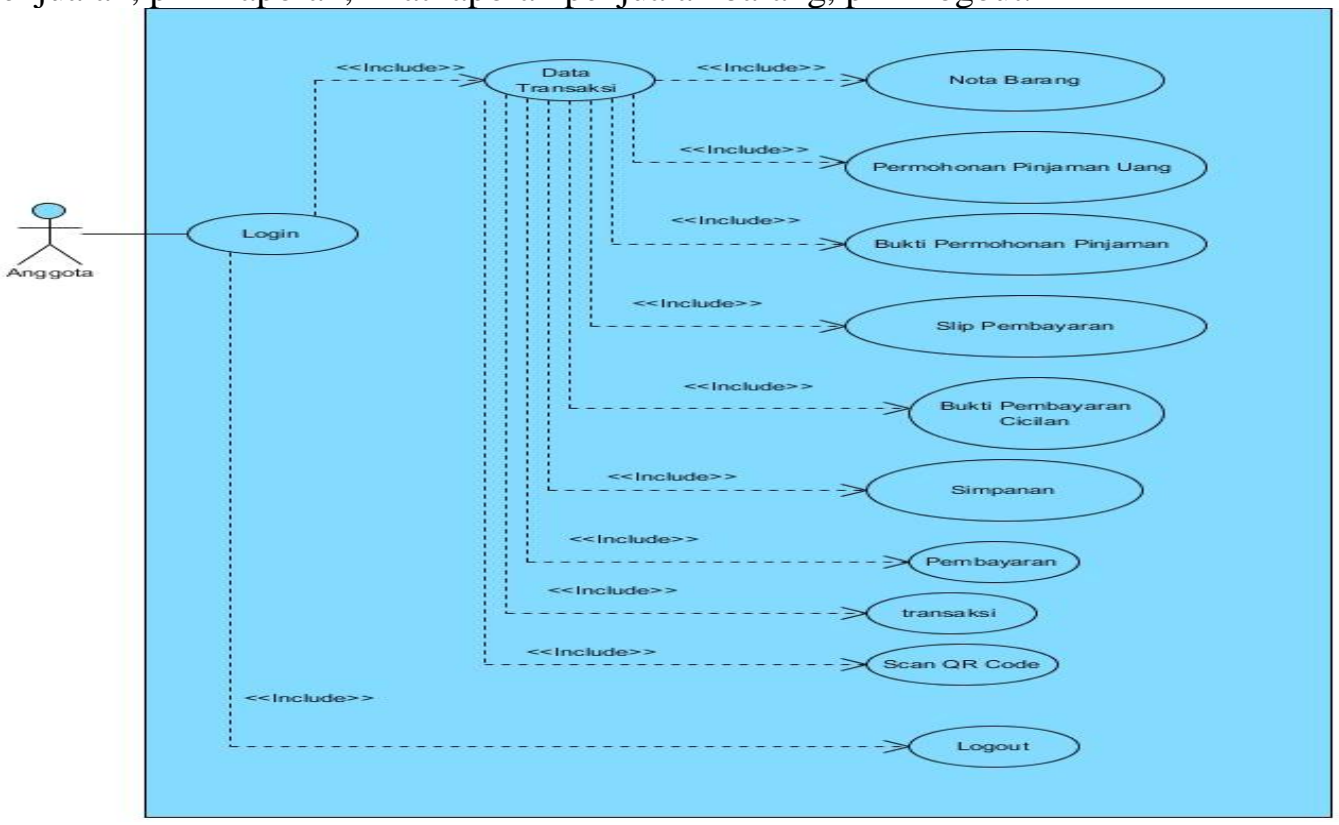

Gambar 7. Use Case Diagram Anggota Usulan

Berdasarkan gambar use case diagram anggota usulan (gambar 7) 1 ( satu ) sistem yang mencakup seluruh kegiatan yang dilakukan oleh anggota Koperasi PT Intikemas Putra Makmur. Terdapat 12 use case yang dapat dilakukan oleh anggota, yaitu login, pilih data transaksi, lihat nota barang, input permohonan pinjaman uang,lihat bukti permohonan pinjaman, lihat slip pembayaran,lihat bukti pembayaran cicilan, lihat simpanan, lihat pembayaran, lihat transaksi, scan QR Code, pilih logout.

Use case diagram sebagai bentuk rancangan sistem yang akan diciptakan (gambar 5, gambar 6, gambar 7) merupakan desain model tampilan utama yang berorintasi pada kebutuhan menu pada aplikasi yang disiapkan, selain itu untuk kebutuhan penyimanan informasi data agar dapat digunakan secara histori juga digambarkan dalam bentuk class diagram (gambar 4) lengkap dengan informasi field dan type data sesuai kebutuhan penyimpanan data.

\section{IMPLEMENTASI}

\section{Rancangan Basis Data}

$\begin{array}{ll}\text { Nama Tabel } & : \text { Karyawan } \\ \text { Media } & : \text { Hardisk } \\ \text { Isi } & \text { Lihat tabel } \\ \text { Panjang Record } & : 86 \text { karakter } \\ \text { Primary Key } & : \text { NIK }\end{array}$

Tabel 1. Tabel Karyawan

\begin{tabular}{|c|l|l|l|l|l|}
\hline No & Nama Field & Akronim & $\begin{array}{l}\text { Type } \\
\text { file }\end{array}$ & Panjang & $\begin{array}{l}\text { Keteranga } \\
\mathrm{n}\end{array}$ \\
\hline 1 & Nomor Induk Karyawan & NIK & Int & 4 & $\begin{array}{l}\text { Primary } \\
\text { Key }\end{array}$ \\
\hline 2 & Nama Karyawan & Nama_karyawan & Char & 30 & \\
\hline
\end{tabular}


ISSN: 2461-1409

Online ISSN: 2655-5298

\begin{tabular}{|l|l|l|l|l|l|}
\hline 3 & Bagian & bagian & Char & 15 & \\
\hline 4 & Alamat & alamat & Text & - & \\
\hline 5 & Tempat lahir & Tempat_lahir & Char & 15 & \\
\hline 6 & Nomor Telefon & No_telp & Big Int & 12 & \\
\hline 7 & Status & Status & Char & 10 & \\
\hline
\end{tabular}

$\begin{array}{ll}\text { Nama Tabel } & : \text { Anggota } \\ \text { Media } & : \text { Hardisk } \\ \text { Isi } & : \text { Lihat tabel } \\ \text { Panjang Record } & : \text { 38 karakter } \\ \text { Primary Key } & : \text { no_anggota }\end{array}$

Tabel 2. Tabel Anggota

\begin{tabular}{|c|l|l|l|l|l|}
\hline No & Nama Field & Akronim & Type file & Panjang & Keterangan \\
\hline 1 & Nomor Anggota & No_anggota & Int & 4 & $\begin{array}{l}\text { Primary } \\
\text { Key }\end{array}$ \\
\hline 2 & Nama Anggota & Nama_anggota & Char & 30 & \\
\hline 3 & Nomor Induk Karyawan & NIK & Int & 4 & \\
\hline 4 & Tanggal Masuk Anggota & TMA & Date & - & \\
\hline
\end{tabular}

$\begin{array}{ll}\text { Nama Tabel } & \text { : Simpanan } \\ \text { Media } & \text { : Hardisk } \\ \text { Isi } & \text { : Lihat tabel } \\ \text { Panjang Record } & : \text { 29 karakter } \\ \text { Primary Key } & \text { : id_simpanan }\end{array}$

Tabel 3. Tabel Simpanan

\begin{tabular}{|c|l|l|l|l|l|}
\hline No & Nama Field & Akronim & $\begin{array}{l}\text { Type } \\
\text { file }\end{array}$ & Panjang & Keterangan \\
\hline 1 & Id Simpanan & Id_simpanan & Char & 5 & $\begin{array}{l}\text { Primary } \\
\text { Key }\end{array}$ \\
\hline 2 & Jenis Simpanan & Jenis_simpanan & Char & 10 & \\
\hline 3 & Jumlah Simpanan & Jumlah_simpanan & Int & 10 & \\
\hline 4 & Nomor Anggota & No_anggota & Int & 4 & \\
\hline
\end{tabular}

Nama Tabel : Form_Permohonan_Pinjaman_Uang

Media : Hardisk

Isi : Lihat tabel

Panjang Record : 30 karakter

Primary Key : no_form_permohonan

Tabel 4. Tabel Form Permohonan Pinjaman Uang

\begin{tabular}{|c|c|l|l|l|l|}
\hline No & \multicolumn{1}{|c|}{ Nama Field } & \multicolumn{1}{c|}{ Akronim } & Type file & Panjang & \multicolumn{1}{|c|}{ Keterangan } \\
\hline 1 & No Form Permohonan & No_form_permohonan & Char & 5 & $\begin{array}{l}\text { Primary } \\
\text { Key }\end{array}$ \\
\hline 2 & Tanggal Permohonan & Tgl_permohonan & Date & - & \\
\hline
\end{tabular}


ISSN: 2461-1409

\begin{tabular}{|l|l|l|l|l|l|}
3 & Nomor Anggota & No_anggota & Int & 4 & \\
\hline 4 & Gaji Terakhir & Gaji_terakhir & Int & 10 & \\
\hline 5 & Jumlah Pinjaman & Jml_pinjaman & Int & 8 & \\
\hline 6 & Lama Angsuran & Lama_angsuran & Int & 3 & \\
\hline 7 & Keperluan & Keperluan & text & - & \\
\hline
\end{tabular}

Nama Tabel : Form_Permohonan_Pinjaman_Karyawan

Media : Hardisk

Isi : Lihat tabel

Panjang Record: 9 karakter

Primary Key : : -

Tabel 5. Tabel Form Permohonan Pinjaman Karyawan

\begin{tabular}{|c|lr|l|l|l|l|}
\hline No & Nama Field & Akronim & Type file & Panjang & Keterangan \\
\hline 1 & $\begin{array}{l}\text { Nomor } \\
\text { Karyawan }\end{array}$ & NIK & Int & 4 & \\
\hline 2 & $\begin{array}{l}\text { Nomor } \\
\text { Permohonan }\end{array}$ & Form & No_form_permohonan & Char & 5 & \\
\hline
\end{tabular}

Nama Tabel : Bukti_Permohonan_Pinjaman

Media : Hardisk

Isi : ( no_bukti + tgl_cetak_bukti + no_form_permohonan)

Panjang Record : 10 karakter

Primary Key : no_bukti

Tabel 6. Tabel Bukti Permohonan Pinjaman

\begin{tabular}{|c|l|l|l|l|l|}
\hline No & Nama Field & Akronim & Type file & Panjang & Keterangan \\
\hline 1 & Nomor Bukti & No_bukti & Char & 5 & Primary Key \\
\hline 2 & Tanggal Cetak Bukti & Tgl_cetak_bukti & Date & - & \\
\hline 3 & $\begin{array}{l}\text { Nomor Form } \\
\text { Permohonan }\end{array}$ & No_form_permohonan & Char & 5 & \\
\hline
\end{tabular}

Nama Tabel : Nota

Media : Hardisk

Isi : ( no_nota + tgl_nota + no_anggota $)$

Panjang Record : 9 karakter

Primary Key : no_nota

Tabel 7. Tabel Nota

\begin{tabular}{|c|l|l|l|l|l|}
\hline No & Nama Field & Akronim & Type file & Panjang & Keterangan \\
\hline 1 & Nomor Nota & No_nota & Char & 5 & Primary Key \\
\hline 2 & Tanggal Nota & Tgl_nota & Date & - & \\
\hline 3 & Nomor Anggota & No_anggota & Char & 5 & \\
\hline
\end{tabular}

Nama Tabel : Nota_Barang

Media : Hardisk

Isi $\quad:($ kd_barang + no_nota + harga + jumlah $)$ 
Panjang Record: 26 karakter

Primary Key

Tabel 8. Tabel Nota Barang

\begin{tabular}{|c|l|l|l|l|l|}
\hline No & Nama Field & Akronim & Type file & Panjang & Keterangan \\
\hline 1 & Kode Barang & kd_barang & Char & 10 & \\
\hline 2 & Nomor Nota & No_nota & Char & 5 & \\
\hline 3 & Harga & harga & Int & 8 & \\
\hline 4 & Jumlah & jumlah & Int & 3 & \\
\hline
\end{tabular}

$\begin{array}{ll}\text { Nama Tabel } & \text { : Barang } \\ \text { Media } & \text { : Hardisk } \\ \text { Isi } & :(\text { kd_barang + nama_barang + harga_barang + satuan + } \\ & \text { jumlah })\end{array}$

Panjang Record: 61 karakter

Primary Key : : kd_barang

Tabel 9. Tabel Barang

\begin{tabular}{|c|l|l|l|l|l|}
\hline No & Nama Field & Akronim & Type file & Panjang & Keterangan \\
\hline 1 & Kode Barang & kd_barang & Char & 10 & Primary Key \\
\hline 2 & Nama Barang & Nama_barang & Char & 30 & \\
\hline 3 & Harga Barang & Harga_barang & Int & 8 & \\
\hline 4 & Satuan & satuan & Char & 10 & \\
\hline 5 & Jumlah & jumlah & Int & 3 & \\
\hline
\end{tabular}

Nama Tabel : Slip_Pembayaran

Media : Hardisk

Isi : ( no_slip + tgl_slip + no_form_permohonan + no_nota $)$

Panjang Record: 15 karakter

Primary Key : no_slip

Tabel 10. Tabel Slip Pembayaran

\begin{tabular}{|c|l|l|l|l|l|}
\hline No & Nama Field & Akronim & Type file & Panjang & Keterangan \\
\hline 1 & Nomor Slip & No_slip & Char & 5 & $\begin{array}{l}\text { Primary } \\
\text { Key }\end{array}$ \\
\hline 2 & Tanggal Slip & Tgl_slip & Date & - & \\
\hline 3 & $\begin{array}{l}\text { Nomor Form } \\
\text { Permohonan }\end{array}$ & No_form_permohonan & Char & 5 & \\
\hline 4 & Nomor Nota & No_nota & Char & 5 & \\
\hline
\end{tabular}

Nama Tabel : Bukti_Pembayaran_Cicilan_Peminjaman

Media : Hardisk

Isi : ( no_bukti_pembayaran + tgl_cetak_bukti + no_slip )

Panjang Record: 10 karakter

Primary Key : no_bukti_pembayara 
ISSN: 2461-1409

Online ISSN: 2655-5298

Tabel 11. Tabel Bukti Pembayaran Cicilan Peminjaman

\begin{tabular}{|c|l|l|l|l|l|}
\hline No & Nama Field & Akronim & Type file & Panjang & Keterangan \\
\hline 1 & No_bukti_pembayaran & $\begin{array}{l}\text { Nomor } \\
\text { Pembayaran }\end{array}$ & Char & 5 & Primary Key \\
\hline 2 & Tgl_cetak_bukti & $\begin{array}{l}\text { Tanggal Cetak } \\
\text { Bukti }\end{array}$ & Date & - & \\
\hline 3 & No_slip & Nomor Slip & Char & 5 & \\
\hline
\end{tabular}

Tabel : Admin

Media : Hardisk

Isi : ( id_admin + nama + Username + password + id_level + foto )

Panjang Record: 129 karakter

Primary Key : id_admin

Tabel 12. Tabel Admin

\begin{tabular}{|l|l|l|l|l|l|}
\hline No & Nama Field & Akronim & Type file & Panjang & Keterangan \\
\hline 1 & Id Admin & Id_admin & Int & 2 & Primary Key \\
\hline 2 & Nama & nama & Varchar & 40 & \\
\hline 3 & User Name & username & Varchar & 15 & \\
\hline 4 & Password & password & Varchar & 10 & \\
\hline 5 & Id Level & Id_level & Int & 2 & \\
\hline 6 & Foto & foto & Varchar & 50 & \\
\hline
\end{tabular}

\section{Rancangan Tampilan}

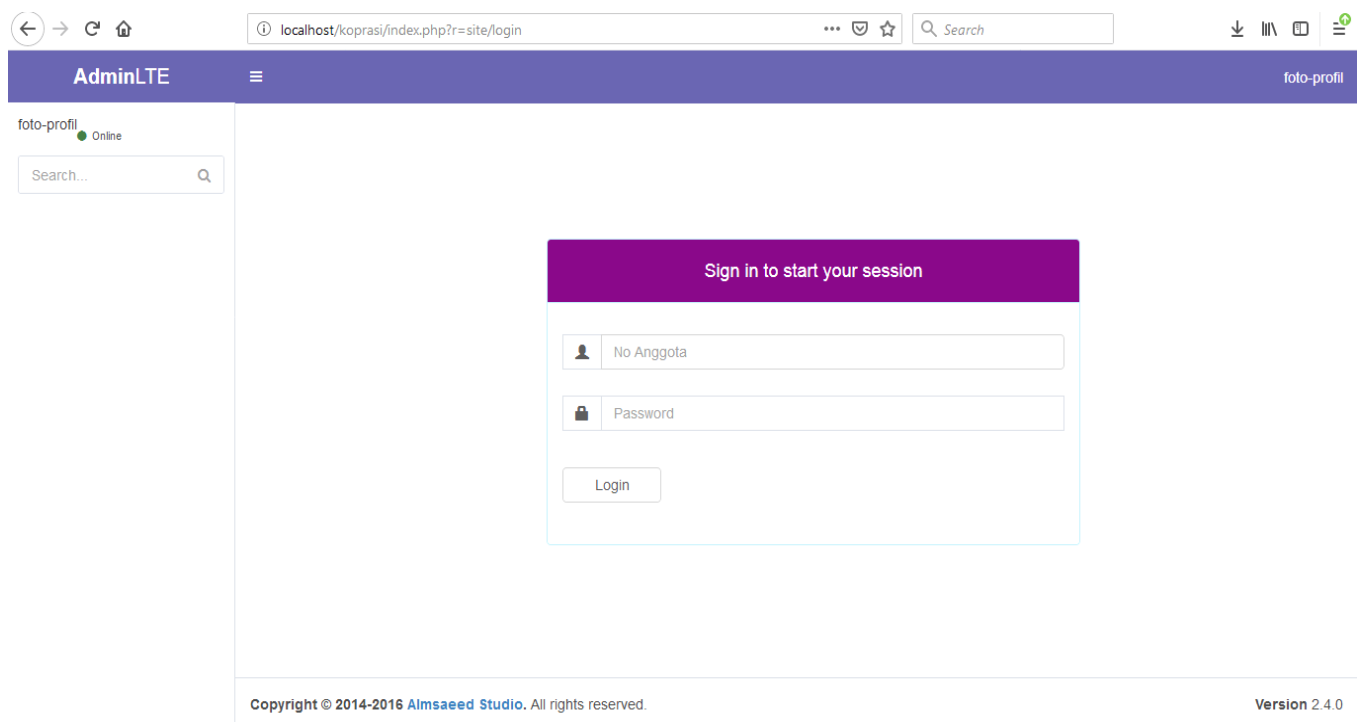

Gambar 8. Tampilan login

Terlihat pada tampilan layar diatas (gambar 8) merupakan tampilan menu login 


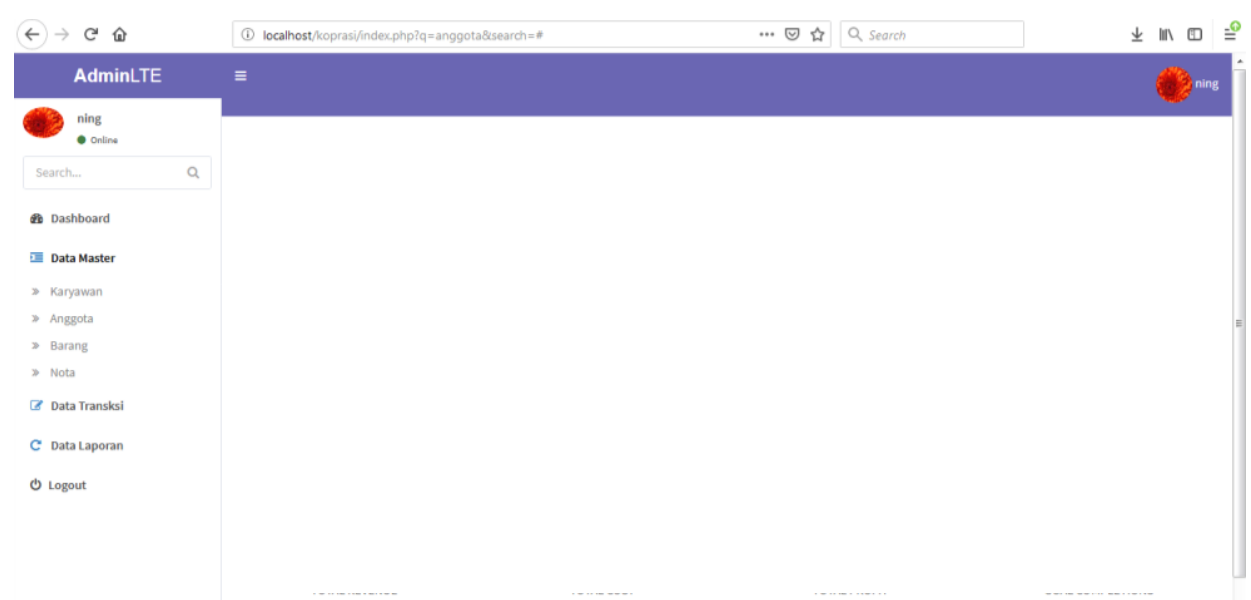

Gambar 9. Tampilan menu utama admin

Terlihat pada tampilan layar diatas (gambar 9) merupakan tampilan layar utama yang terdiri dari menu master, menu transaksi dan menu laporan, dimana menu master memiliki sub menu karyawan, aggota, barang, nota.

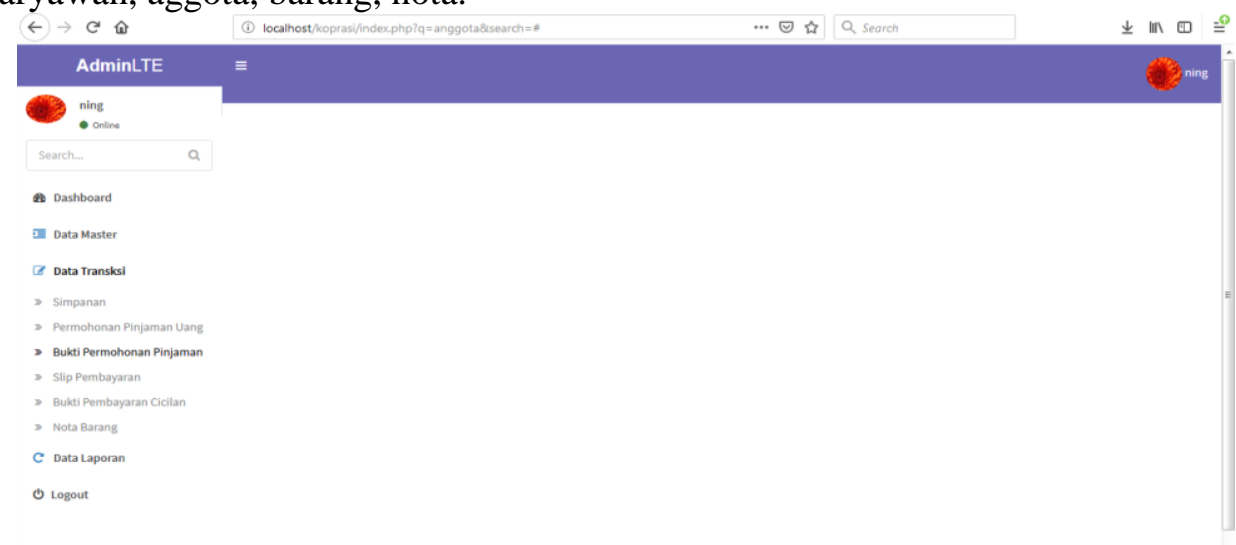

Gambar 10. Tampilan menu transaksi

Terlihat pada tampilan layar diatas (gambar 10) merupakan tampilan layar utama yang terdiri dari menu master, menu transaksi dan menu laporan, dimana menu transaksi memiliki sub simpanan, permohonan pinjaman uang, bukti permohonan pinjaman, slip pembayaran, bukti pembayaran cicilan, nota barang.

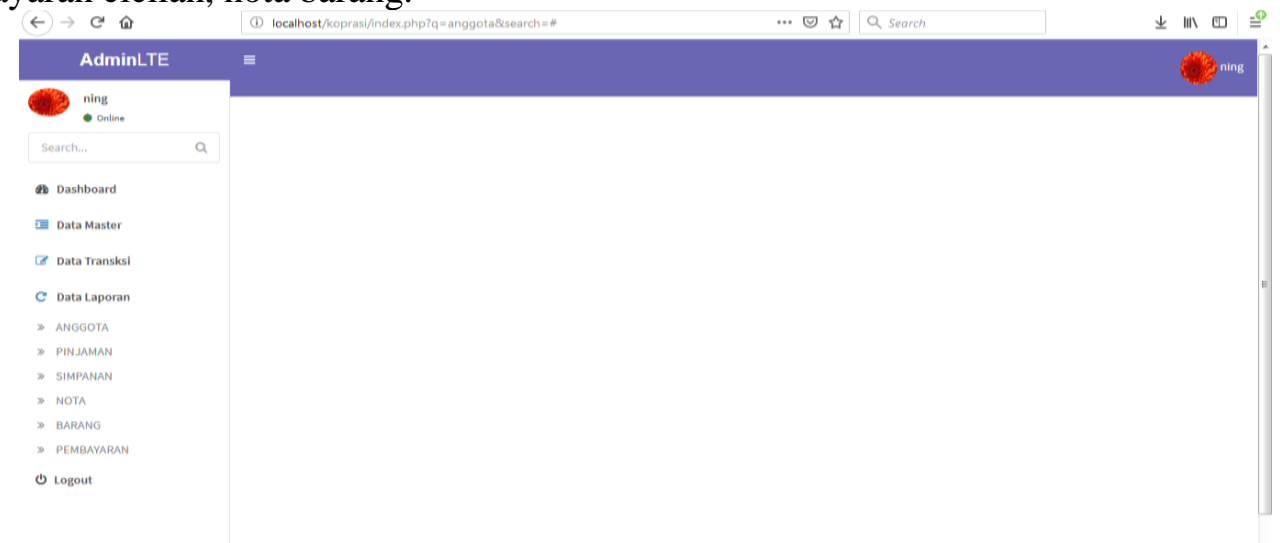

Gambar 11. Tampilan menu laporan 
Terlihat pada tampilan layar diatas (gambar 11) merupakan tampilan layar utama yang terdiri dari menu master, menu transaksi dan menu laporan, dimana menu laporan memiliki sub Anggota, Pinjaman, Simpanan, Nota, Barang, Pemnbayaran.

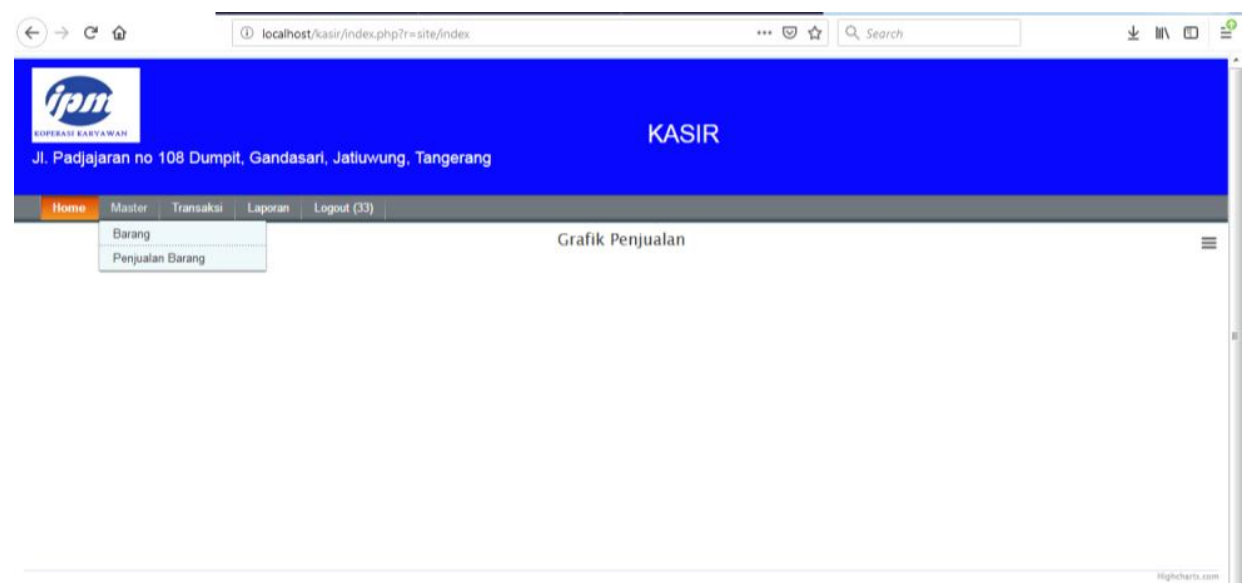

Gambar 12. Tampilan menu kasir

Terlihat pada tampilan layar diatas (gambar 12) merupakan tampilan layar kasir yang terdiri dari menu home, master, transaksi, laporan, dan logout.

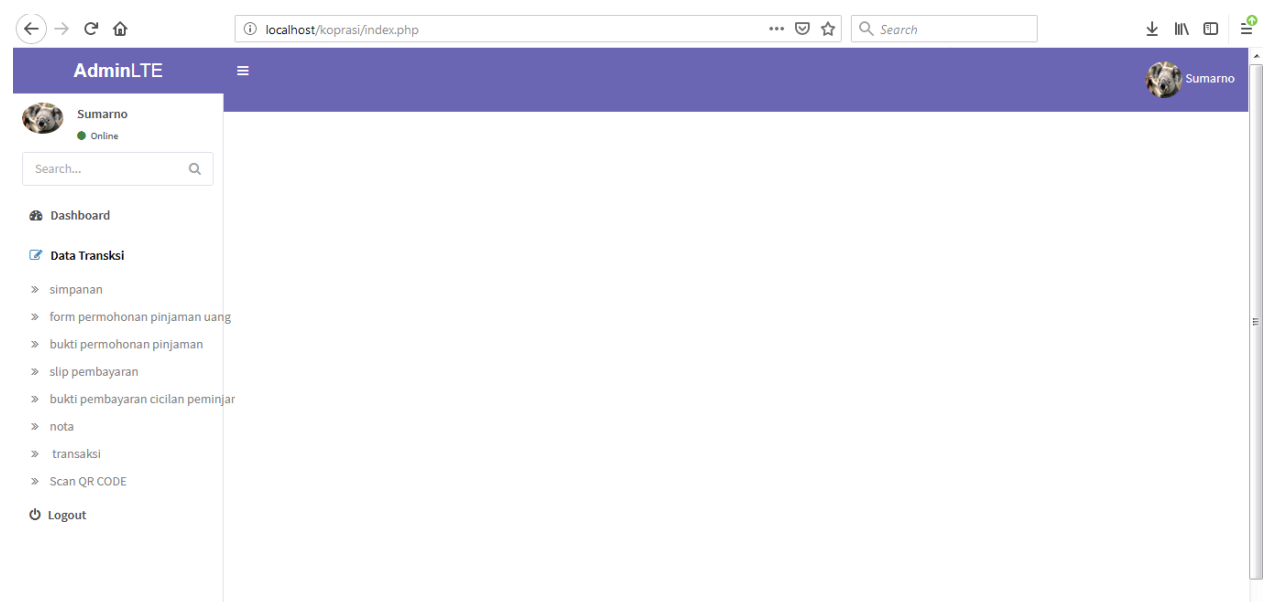

Gambar 13. Tampilan menu anggota

Terlihat pada tampilan layar diatas (gambar 13) merupakan tampilan layar anggota yang terdiri dari menu transaksi dan logout.

\section{KESIMPULAN}

Berdasarkan analisa lapangan, dan pelaksanaan implementasi penelitian, pada Koperasi Pt Intikemas Putra Makmur, maka terdapat beberapa kesimpulan sebagai berikut, Sistem koperasi masih manual menggunakan buku koperasi dan Microsoft Excel dalam penginputan data anggota serta data transaksi sehingga keamanan data tidak terjamin, anggota koperasi mengajukan permohonan pinjaman harus menemui petugas koperasi untuk meminta formulir permohonan pinjaman, pengadaan buku koperasi membutuhkan dana dan rentan hilang, juga belum tersedia sistem penjulan barang. Rancangan yang peneliti ingin buat berupa pelayanan dan pelaporan koperasi, dimana petugas koperasi tidak menggunakan buku koperasi dan hanya menggunakan sistem yang disediakan, anggota koperasi dapat mengakses akun anggota untuk 
mengetahui data transaksi masing-masing ataupun mengajukan formulir pengajuan peminjaman secara online, serta menyediakan sistem untuk transaksi penjualan dan pembelian. Penulis ingin membuat sebuah sistem yang mengaplikasikan Scan QR Code, dimana QR Code digunakan untuk melakukan pembayaran dalam transaksi pembelian, anggota yang melakukan pembelian pada koperasi, cukup scan kode nota pada aplikasi kasir, maka data transaksi pembelian akan masuk ke akun anggota dan menjadi laporan pada aplikasi admin.

\section{DAFTAR PUSTAKA}

[1] Junaidi, Junaidi, Ladyca Anugrah, and Adhitya Dwi Pancasakti. "Model Aplikasi Monitoring Sistem Absensi Sidik Jari Sebagai Pendukung Keputusan Untuk Penilaian Kinerja Pegawai." Proceedings Konferensi Nasional Sistem dan Informatika (KNS\&I) (2015).

[2] Supriyanto, Agn. 2015. Tata Kelola Koperasi Kredit Atau Koperasi Simpan Pinjam. Yogyakarta : Penerbit Andi.

[3] Junaidi, Junaidi, Abdul Roji, and Kharis Munawar. "Konsep Otomatisasi Sistem Pembayaran SPP Online Untuk Mengurangi Tingkat Keterlambatan." Proceedings Konferensi Nasional Sistem dan Informatika (KNS\&I) (2015).

[4] Henderi, Henderi, Junaidi Junaidi, and Tubagus Ahmad Harja Kusuma. "Dashboard Monitoring System Penjualan Dan Reward Mobile Kios PT. Telekomunikasi Seluler." Semantik 2.1 (2012).

[5] Muharom, Lutfi Ali. “Penerapan Model Presensi Ujian Semester Berbasis Quick Response Code (QR Code) di Universitas Muhammadiyah Jember". JUSTINDO 1.2 (2016).

[6] Junaidi, Junaidi, Ridwan Arifin, and Amanda Septiani. "Rancang Bangun Aplikasi Sistem Inventory Berbasis Desktop Menggunakan JSE." Proceedings Konferensi Nasional Sistem dan Informatika (KNS\&I) (2015).

[7] Hernikawati, Dewi. “ Indeks Kepuasan Masyarakat Terhadap Layanan Komunikasi Data Di Pjkkd Batan”. Jurnal Studi Komunikasi Dan Media 22.1 (2018).

[8] Junaidi, Junaidi, Abdul Roji, and Kharis Munawar. "Konsep Otomatisasi Sistem Pembayaran SPP Online Untuk Mengurangi Tingkat Keterlambatan." Proceedings Konferensi Nasional Sistem dan Informatika (KNS\&I) (2015).

[9] Junaidi, Junaidi, Ridwan Arifin, and Amanda Septiani. "Rancang Bangun Aplikasi Sistem Inventory Berbasis Desktop Menggunakan JSE." Proceedings Konferensi Nasional Sistem dan Informatika (KNS\&I) (2015).

[10] Junaidi, Junaidi, Novi Cholisoh, and Nur Hasanah. "Rancang Bangun Sistem Manajemen Aset IT Untuk Pencatatan History Maintenance Sebagai Pendukung Keputusan." SENSI Journal 4.2 (2018): 220-231.

[11 Junaidi, Junaidi, Retno Setianingsih, and Khusnul Khotimah. "Rancang Bangun Sistem Penerimaan Dan Pengeluaran Barang Menggunakan Java Aplikasi." Proceedings Konferensi Nasional Sistem dan Informatika (KNS\&I) (2015).

[12] Junaidi, Junaidi, Sugeng Santoso, and Lusyani Sunarya. "Rekayasa Teknik Pemrograman Pencegahan Dan Perlindungan Dari Virus Lokal Menggunakan API Visual Basic." CCIT Journal 1.2 (2008): 134-153. 